\title{
IMPLEMENTATION OF THE REFERRAL SYSTEM POLICY IN THE NATIONAL HEALTH INSURANCE SCHEME AT COMMUNITY HEALTH CENTERS, NGAWI DISTRICT, EAST JAVA
}

\author{
Maria Yeny Eskawati1 ${ }^{1)}$, Bhisma Murti ${ }^{1)}$, Didik Gunawan Tamtomo ${ }^{2)}$ \\ ${ }^{1)}$ Masters Program in Public Health, Sebelas Maret University \\ 2)Department of Anatomy, Faculty of Medicine, Sebelas Maret University
}

\begin{abstract}
Background: It has been reported that there are some obstacles in the implementation of the National Health Insurance, one of which is its referral system. Community Health Center is expected to serve as a gatekeeper, such that most of the health problems can be tackled at the Community Health Center. However, anecdotal evidences had shown that the referral system did not run as expected. This study aimed to examine the implementation of the referral system in the National Health Insurance scheme with special attention on the policy context and resources availability at Community Health Centers in Ngawi, East Java.
\end{abstract}

Subjects and Method: This was a qualitative study conducted in Ngawi, East Java. The institutions under study included 3 Community Health Centers of different strata Geminggar Community Health Center (highest strata), Ngawi Community Health Center (medium strata), Kasreman Community Health center (lowest strata). The other institution under study was Ngawi District Health Office. The informants for this study included 24 patients of various categories at Community Health Center: subsidy recipients, class I, class II, and class III. The other informants included 1 staff from District Health Office and 6 staff from Community Health Center. The data were collected by in-depth interview, observation, and document review. The data were analyzed by data reduction, presentation, and verification.

Results: The policy on the referral system of the National Health Insurance (NHI) was good but its implementation was poor. Outpatient referral was still high because of community ignorance regarding referral system. It was often the case the referral was based on patient request. The referral system problem also stemmed from the shortage of medical doctors and health equipment at the Community Health Center. Nevertheless, the availability of medicine and funding at Community Health Center were sufficient. The sources of funding included General Allocation Fund (DAU), Special Allocation Fund (DAK), Special Allocation Fund for Operational Affairs (BOK), and capitation. Community Health Center only managed capitation and BOK.

Conclusion: There is a need for socialization to the community regarding the current referral system of the National Health Insurance either through the media or the BPJS representative at the Community Health Center. In addition, there is a need for recruitment of doctors with a clear salary regulation, and health equipment upgrade at Community Health Center.

Keywords: Referral system, resources, National Health Insurance sistem rujukan, sumberdaya, Jaminan Kesehatan Nasional

Correspondence: Maria Yeny Eskawati. Masters Program in Public Health, Sebelas Maret University, Jl. Ir. Sutami 36 A, Surakarta 57126, Central Java. Mobile: +6282230898979 . 